\title{
Crank Arm Assembly Device
}

National Cancer Institute

\section{Source}

National Cancer Institute. Crank Arm Assembly Device. NCI Thesaurus. Code C49898.

An extension to a shaft designed to impart a rotational energy to the shaft. 